\title{
Impact of Standing Bleed Water on Saltstone Placement
}

\author{
A. D. Cozzi \\ B. R. Pickenheim
}

September 2012

Savannah River National Laboratory Savannah River Nuclear Solutions, LLC Aiken, SC 29808

Prepared for the U.S. Department of Energy under contract number DE-AC09-08SR22470. 
SRNL-STI-2012-00546

Revision 0

\section{DISCLAIMER}

This work was prepared under an agreement with and funded by the U.S. Government. Neither the U.S. Government or its employees, nor any of its contractors, subcontractors or their employees, makes any express or implied:

1. warranty or assumes any legal liability for the accuracy, completeness, or for the use or results of such use of any information, product, or process disclosed; or

2. representation that such use or results of such use would not infringe privately owned rights; or

3. endorsement or recommendation of any specifically identified commercial product, process, or service.

Any views and opinions of authors expressed in this work do not necessarily state or reflect those of the United States Government, or its contractors, or subcontractors.

\section{Printed in the United States of America}

Prepared for U.S. Department of Energy 
Keywords: Saltstone, Saltstone

Disposal Unit

Retention: Permanent

\title{
Impact of Standing Bleed Water on Saltstone Placement
}

\author{
A. D. Cozzi \\ B. R. Pickenheim
}

September 2012

Savannah River National Laboratory Savannah River Nuclear Solutions, LLC Aiken, SC 29808

Prepared for the U.S. Department of Energy under contract number DE-AC09-08SR22470. 


\section{REVIEWS AND APPROVALS}

AUTHORS:

A. D. Cozzi, Engineering Process Development

Date

B. R. Pickenheim, Engineering Process Development

Date

TECHNICAL REVIEW:

W. E. Daniel, Engineering Process Development

Date

P. M. Almond, Engineering Process Development

Date

APPROVAL:

K. M. Fox, Manager

Date

Engineering Process Development

S. L. Marra, Manager

Date

Environmental \& Chemical Process Technology Research Programs

J. E. Occhipinti, Manager

Date

Waste Solidification Engineering 


\section{EXECUTIVE SUMMARY}

The amount of water present during placement and subsequent curing of saltstone has the potential to impact several properties important for grout quality. An active drain water system can remove residual standing water and expose the surface of the placed saltstone to air. Oxidation of the saltstone may result in an increase in the leachability of redox sensitive elements. A dry surface can lead to cracking, causing an increase in hydraulic conductivity. An inactive drain water system can allow standing water that generates unnecessary hydrostatic head on the vault walls. Standing water that cannot be removed via the drain system will be available for potential incorporation into subsequent grout placements.

The objective of this work is to study the impact of standing water on grout quality pertaining to disposal units. A series of saltstone mixes were prepared, and cured at ambient temperature to evaluate the impact of standing water on saltstone placement. The samples were managed to control drying effects on leachability by either exposing or capping the samples. The water to premix ratio was varied to represent a range of processing conditions. Samples were analyzed for density, leachability, and hydraulic conductivity.

A monolith of each composition was cut into four sections to analyze the homogeneity of the sample with respect to vertical position within the sample. The density of each section was measured by two methods, helium pycnometry and by ASTM 642-06. The results show a trend of increasing density with increasing depth in the samples. This effect is more pronounced with the inclusion of excess bleed water and indicative of increased settling.

The leachability of the eight different samples was analyzed by ANS/ANSI 16.1 method. These results indicate that drying of the saltstone during curing leads to decreased Leachability Indices (indicative of more release) for potassium, sodium, rhenium, nitrite, and nitrate. This may be caused by shrinkage cracking in the samples creating additional pathways for contaminant release. There was no noticeable effect on leachability by changing the water to premix ratio or by including excess bleed water.

There was no detectable chromium release in any of the samples. Chromium and rhenium were added in equal amounts to determine whether rhenium might be an acceptable surrogate for chromium, a hazardous material. This testing shows no correlation between the behavior of the two elements, as chromium is not released at detectable levels and rhenium is released at a comparable rate to nitrate, the most prevalent and mobile species in saltstone. 


\section{TABLE OF CONTENTS}

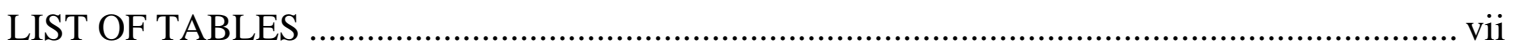

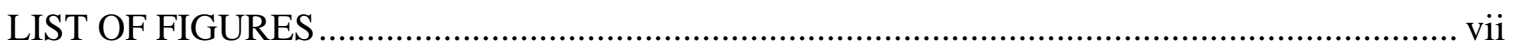

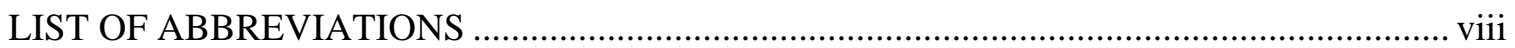

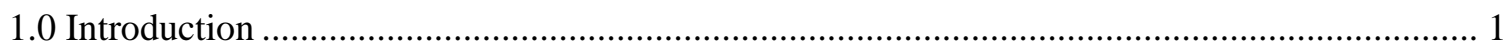

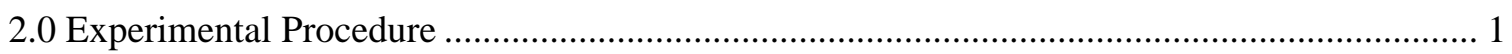

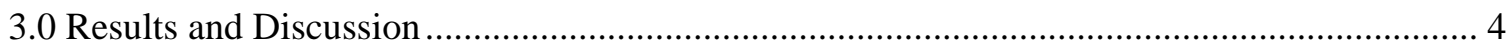

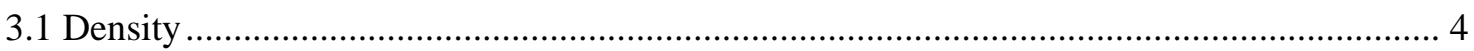

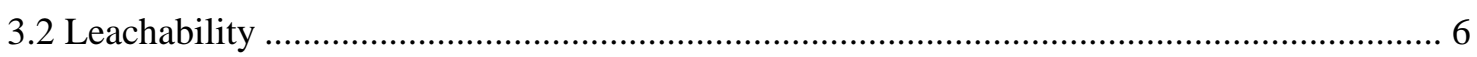

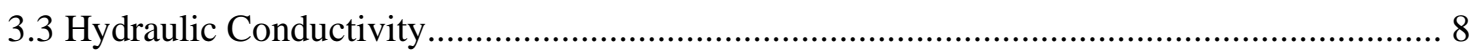

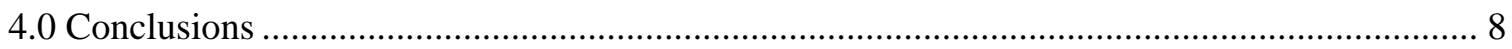

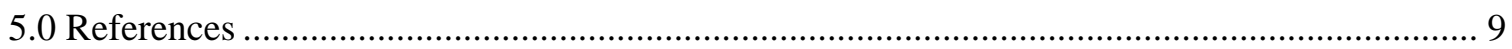




\section{LIST OF TABLES}

Table 2-1. Simulant Salt Solution Based on CY11 WAC Analysis .............................................. 2

Table 2-2. Test Conditions to Evaluate the Effect of Placing Saltstone into Standing Water........ 3

Table 3-1. Density of Sectioned Monoliths .................................................................................. 5

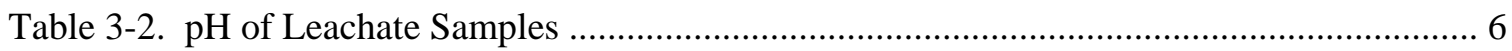

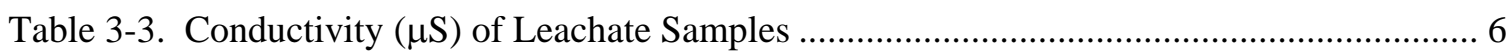

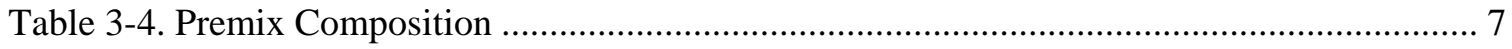

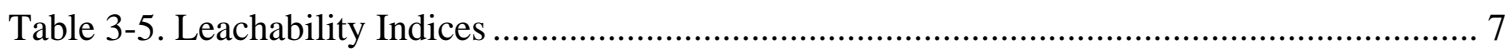

\section{LIST OF FIGURES}

Figure 2-1. Sectioning of Samples for Particle Settling Evaluation............................................. 4

Figure 3-1. Density of Sectioned Monoliths ............................................................................ 5 


\section{LIST OF ABBREVIATIONS}

IC

ICP-ES Inductively Coupled Plasma Emission Spectroscopy

LI Leachability Index

PA Performance Assessment

SCHWMR South Carolina Hazardous Waste Management Regulations

SDF Saltstone Disposal Facility

SDU Saltstone Disposal Unit

SFT Saltstone Feed Tank

SPF Saltstone Production Facility

SRNL Savannah River National Laboratory

SRR-WSE Savannah River Remediation - Waste Solidification Engineering

TS Total Solids

TTQAP Task Technical and Quality Assurance Plan

TTR Task Technical Request

w/p Water to premix ratio

WAC Waste Acceptance Criteria 


\subsection{Introduction}

Prior to 2003 in Vault 4, excess water that accumulated between the saltstone grout and the vault wall was removed by drain valves into carboys and returned to the Saltstone Feed Tank (SFT). The removal of water was intended to relieve the SDF of the potential for hydrostatic head due to accumulation between the saltstone grout and the vault wall. ${ }^{1}$ A sheet drain system was added in 2003 to the Saltstone Disposal Facility (SDF) to facilitate the removal of water with a greater associated dose of radionuclides. The current drain water collection system has not maintained the operational availability necessary to support the Saltstone Production Facility (SPF) throughput. $^{2}$

The presence, or absence, of a moist environment for the curing of saltstone has the potential to impact several properties of the emplaced product. An active drain water system can remove residual standing water and expose the surface of the placed saltstone to air. Oxidation of the saltstone may result in an increase in the leachability of redox sensitive elements. A dry surface can lead to cracking, causing an increase in hydraulic conductivity. An inactive drain water system can generate unnecessary hydrostatic head on the vault walls and standing water that cannot be removed via the drain system and will be available for potential incorporation into subsequent grout placements.

Savannah River Remediation-Waste Solidification Engineering (SRR-WSE) has requested through a Task Technical Request (TTR) that the Savannah River National Laboratory determine the impacts of the availability of the sheet drain on select properties of placed saltstone. ${ }^{3}$ This work was performed under the guidance of a Task Technical and Quality Assurance Plan (TTQAP). ${ }^{4}$

\subsection{Experimental Procedure}

A simplified salt solution was made based on the CY11 Waste Acceptance Criteria (WAC) analysis of Tank $50 \mathrm{H}^{5}$ with elevated quantities $(1000 \mathrm{mg} / \mathrm{L})$ of chromium and rhenium as surrogates for technetium-99 (Table 2-1). Chromium and rhenium are added in identical quantities to evaluate whether a correlation exists between the two components. Demonstration of this correlation would support the use of the nonhazardous rhenium as a surrogate for the chromium (chromium is hazardous for toxicity, South Carolina Hazardous Waste Management Regulations (SCHWMR) R.61-79.261.24). The salt solution has total weight percent solids (TS) of $25.13 \%$ and a density of $1.207 \mathrm{~g} / \mathrm{ml}$. 
Table 2-1. Simulant Salt Solution Based on CY11 WAC Analysis

\begin{tabular}{||c|c|c|c||}
\hline Compound & g/L & Component & M \\
\hline Water & balance & $\mathrm{Na}$ & $4.42 \mathrm{E}+00$ \\
\hline $\mathrm{KNO}_{3}$ & 0.55 & $\mathrm{Al}$ & $1.12 \mathrm{E}-01$ \\
\hline $\mathrm{NaNO}_{3}$ & 154.37 & $\mathrm{Cr}$ & $1.91 \mathrm{E}-02$ \\
\hline $\mathrm{NaOH}(50 \%)$ & 142.4 & $\mathrm{Re}$ & $5.31 \mathrm{E}-03$ \\
\hline $\mathrm{Al}\left(\mathrm{NO}_{3}\right)_{3} \cdot 9 \mathrm{H}_{2} \mathrm{O}$ & 42.01 & $\mathrm{~B}$ & $1.1 \mathrm{E}-02$ \\
\hline $\mathrm{NaNO}_{2}$ & 25.66 & $\mathrm{~K}$ & $5.4 \mathrm{E}-03$ \\
\hline $\mathrm{Na}_{2} \mathrm{CO}_{3}$ & 14.73 & $\mathrm{NO}_{3}$ & $2.16 \mathrm{E}+00$ \\
\hline $\mathrm{Na}_{2} \mathrm{SO}_{4}$ & 6.59 & $\mathrm{NO}_{2}$ & $3.7 \mathrm{E}-01$ \\
\hline $\mathrm{Na}_{2} \mathrm{CrO}_{4}$ & 3.12 & $\mathrm{OH}_{3}$ & $1.8 \mathrm{E}+00$ \\
\hline $\mathrm{Na}_{3} \mathrm{PO}_{4} \cdot 12 \mathrm{H}_{2} \mathrm{O}$ & 1.909 & $\mathrm{CO}_{3}$ & $1.4 \mathrm{E}-01$ \\
\hline $\mathrm{NaReO}_{4}$ & 1.468 & $\mathrm{SO}_{4}$ & $4.6 \mathrm{E}-02$ \\
\hline $\mathrm{Na}_{2} \mathrm{C}_{2} \mathrm{O}_{4}$ & 1.24 & $\mathrm{C}_{2} \mathrm{O}_{4}$ & $9.3 \mathrm{E}-03$ \\
\hline $\mathrm{H}_{3} \mathrm{BO}_{3}$ & 0.71 & $\mathrm{Cl}$ & $4.6 \mathrm{E}-03$ \\
\hline $\mathrm{NaCl}$ & 0.27 & & \\
\hline
\end{tabular}

A series of saltstone mixes were prepared as in previous studies ${ }^{6}$, cast into duplicate molds, and cured at ambient temperature. 3" x 6” (nominal) samples were prepared for hydraulic conductivity testing and 1" x 4" (nominal) samples were cast for density and leachability testing. The samples were managed to control drying effects on leachability by either exposing or capping the samples. Samples to be exposed were cast into steel molds, demolded after seven days, and set out exposed to ambient conditions. Samples to be maintained as moist were cast in plastic cylinders and capped. The water to premix (w/p) ratio was varied to represent the different processing conditions described in the Technical Task Request (TTR). ${ }^{3}$

Table 2-2 shows the different placement conditions that were evaluated. Further descriptions of each test are provided below:

1. $0.60 \mathrm{w} / \mathrm{p}$. Sample is poured into empty cylinder and cured exposed to the atmosphere - representative of a zero bleed mix with a sheet drain present to wick salt solution.

2. $\quad 0.60 \mathrm{w} / \mathrm{p}$. Sample is poured into empty cylinder and is cured in a humid atmosphere — representative of a zero bleed mix with no sheet drain.

3. $0.60 \mathrm{w} / \mathrm{p}$. Sample is poured into empty cylinder and is cured with $5 \%$ excess water added after gel — representative of a controlled bleed mix with no sheet drain.

4. $\quad 0.60 \mathrm{w} / \mathrm{p}$. Sample is poured into cylinder containing salt solution equal to $10 \%$ of the salt solution in the mix and cured in a humid atmosphere - representative of startup after a run shortened by a setback.

5. $0.64 \mathrm{w} / \mathrm{p}$. Sample is poured into empty cylinder and is cured exposed to the atmosphere - representative of a mix with all process flushes included and a sheet drain present to wick salt solution.

6. $\quad 0.64 \mathrm{w} / \mathrm{p}$. Sample is poured into empty cylinder and is cured in a humid atmosphere - representative of a mix with all process flushes included with no sheet drain present. 
7. $\quad 0.64 \mathrm{w} / \mathrm{p}$. Sample is poured into cylinder containing salt solution equal to $5 \%$ of the salt solution in the mix and cured in a humid atmosphere - representative of a mix with all process flushes included pouring into standing water for an extended period.

8. $\quad 0.64 \mathrm{w} / \mathrm{p}$. Sample is poured into cylinder containing salt solution equal to $10 \%$ of the salt solution in the mix and cured in a humid atmosphere - representative of a mix with all process flushes included pouring into standing water after a run shortened by a setback.

Table 2-2. Test Conditions to Evaluate the Effect of Placing Saltstone into Standing Water

\begin{tabular}{|c|c|c|c|c|}
\hline Test & w/p & Height & Standing Water (salt solution) & Cure Conditions \\
\hline 1 & 0.60 & 0 & None & Fully Exposed \\
\hline 2 & 0.60 & 0 & None & Sealed \\
\hline 3 & 0.60 & $7.4 \mathrm{~mm}^{*}$ & $\begin{array}{c}33.9 \mathrm{ml} \text { added after placement } \\
(4.7 \mathrm{~g} \text { for small monoliths })\end{array}$ & Sealed \\
\hline 4 & 0.60 & $14.9 \mathrm{~mm}^{\dagger}$ & $\begin{array}{c}67.8 \mathrm{ml} \text { added before placement } \\
(9.4 \mathrm{~g} \text { for small monoliths })\end{array}$ & Sealed \\
\hline 5 & 0.64 & 0 & None & Fully Exposed \\
\hline 6 & 0.64 & 0 & None & Sealed \\
\hline 7 & 0.64 & $7.4 \mathrm{~mm}^{*}$ & $\begin{array}{c}33.9 \mathrm{ml} \text { added before placement } \\
(4.7 \mathrm{~g} \text { for small monoliths })\end{array}$ & Sealed \\
\hline 8 & 0.64 & $14.9 \mathrm{~mm}^{\dagger}$ & $\begin{array}{c}67.8 \mathrm{ml} \text { added before placement } \\
\text { (9.4 for small monoliths) }\end{array}$ & Sealed \\
\hline \multicolumn{5}{|c|}{ *Corresponds to $5 \%$ bleed calculated from total volume of pour. } \\
†Corresponds to $10 \%$ bleed calculated from total volume of pour.
\end{tabular}

The degradation and contaminant movement though saltstone is used in the saltstone Performance Assessment (PA) to model the release of contaminants to the environment. ${ }^{7}$ After curing for 28 days, the samples were demolded and leached, using the ANSI/ANS 16.1 standard test. $^{8}$ To perform this test, samples were suspended in bottles containing deionized water as a leachant, lifted out at set times and placed in new bottles with fresh leachant. The time periods for the leachate testing were 2, 7, 24, 48, 72, 96, and 120 hours. At the end of each elapsed time period, samples were collected for analysis by Ion Chromatography (IC) measurements of nitrite $\left(\mathrm{NO}_{2}{ }^{-}\right)$, nitrate $\left(\mathrm{NO}_{3}{ }^{-}\right)$, and oxalate $\left(\mathrm{C}_{2} \mathrm{O}_{4}{ }^{2-}\right)$ concentrations, and Inductively Coupled Plasma Emission Spectroscopy (ICP-ES) measurements of aluminum, calcium, chromium, potassium, sodium, and rhenium concentrations. Additional samples were collected for $\mathrm{pH}$ and conductivity measurements.

The transport of water through saltstone is an input parameter to the numerical model that supports the saltstone PA. ${ }^{9}$ The saltstone PA supports the satisfaction of DOE Order 435.1, "Radioactive Waste Management." Samples from each of the test conditions were measured to determine the effect of the saltstone placement on the hydraulic conductivity. Samples were sent offsite for testing by AMEC, Atlanta, Ga.

Demonstration of homogeneity of the saltstone mix can reduce variability in the material properties used in the modeling effort. The hydraulic components of premix, cement and slag, are both denser than the fly ash. To evaluate segregation of particles, additional samples were cast into 1" x 4" cylinders. After curing, the samples were sectioned into discs as shown in Figure 2-1. The density of each disc was calculated by using the volume measured by helium pycnometry 
and confirmed by ASTM C642-06. The ASTM method describes determining the dry and saturated masses of the samples after oven drying, immersion and boiling. These masses are used to calculate dry, saturated, and apparent density of the sample.

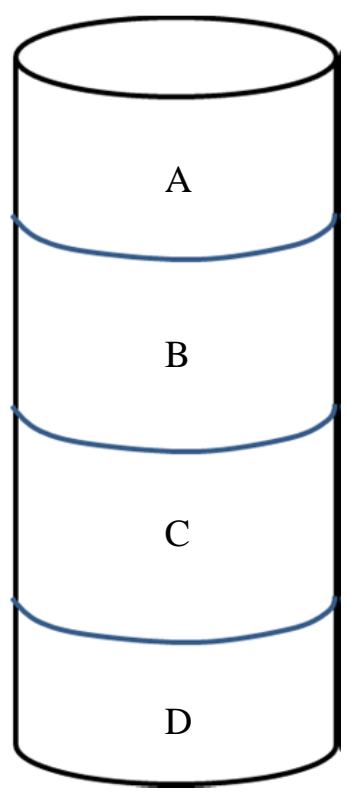

Figure 2-1. Sectioning of Samples for Particle Settling Evaluation.

A pycnometer uses a pressurized gas, in this case helium, to fill a chamber containing a sample and a reference chamber. The pressure difference between the two chambers can be used to calculate the volume of the sample by Boyle's Law:

Where $\mathrm{V}_{\mathrm{s}}=$ volume of sample, $\mathrm{V}_{\mathrm{C}}=$ volume of sample chamber, $\mathrm{V}_{\mathrm{R}}=$ volume of reference cell

The calculated volume is then used with the directly measured mass of the sample to calculate the density of the sample.

\subsection{Results and Discussion}

\subsection{Density}

The saturated density values obtained via pycnometry and ASTM C642-06 are contained in Table 3-1. The relative percent difference between the two methods is calculated for comparative purposes. The data are also presented graphically in Figure 3-1 to better demonstrate the presence of density gradients observable in some of the samples. 
Table 3-1. Density of Sectioned Monoliths

\begin{tabular}{|c|c|c|c|c|c|c|c|}
\hline $\begin{array}{l}\text { Sample } \\
\text { ID }\end{array}$ & $\begin{array}{c}\text { Pycnometer } \\
\text { Density } \\
{\left[\mathrm{g} / \mathrm{cm}^{3}\right]} \\
\end{array}$ & $\begin{array}{c}\text { ASTM } \\
\text { Density } \\
{\left[\mathrm{g} / \mathrm{cm}^{3}\right]}\end{array}$ & $\begin{array}{c}\text { Percent } \\
\text { Difference }\end{array}$ & $\begin{array}{c}\text { Sample } \\
\text { ID }\end{array}$ & $\begin{array}{c}\text { Pycnometer } \\
\text { Density } \\
{\left[\mathrm{g} / \mathrm{cm}^{3}\right]} \\
\end{array}$ & $\begin{array}{l}\text { ASTM } \\
\text { Density } \\
{\left[\mathrm{g} / \mathrm{cm}^{3}\right]} \\
\end{array}$ & $\begin{array}{c}\text { Percent } \\
\text { Difference }\end{array}$ \\
\hline $1-1 \mathrm{~A}$ & 1.724 & 1.692 & $1.89 \%$ & 5-1A & 1.738 & 1.695 & $2.56 \%$ \\
\hline 1-1B & 1.687 & 1.686 & $0.05 \%$ & 5-1B & 1.747 & 1.702 & $2.67 \%$ \\
\hline $1-1 \mathrm{C}$ & 1.749 & 1.697 & $3.06 \%$ & 5-1C & 1.743 & 1.715 & $1.67 \%$ \\
\hline $1-1 \mathrm{D}$ & 1.765 & 1.708 & $3.32 \%$ & 5-1D & 1.728 & 1.713 & $0.89 \%$ \\
\hline $2-1 \mathrm{~A}$ & 1.747 & 1.696 & $3.03 \%$ & $6-1 \mathrm{~A}$ & 1.703 & 1.685 & $1.08 \%$ \\
\hline $2-1 B$ & 1.724 & 1.701 & $1.35 \%$ & $6-1 B$ & 1.715 & 1.685 & $1.79 \%$ \\
\hline $2-1 C$ & 1.749 & 1.699 & $2.99 \%$ & 6-1C & 1.698 & 1.685 & $0.79 \%$ \\
\hline $2-1 D$ & 1.756 & 1.712 & $2.59 \%$ & 6-1D & 1.704 & 1.693 & $0.66 \%$ \\
\hline $3-1 \mathrm{~A}$ & 1.724 & 1.692 & $1.93 \%$ & $7-1 \mathrm{~A}$ & 1.644 & 1.637 & $0.38 \%$ \\
\hline $3-1 B$ & 1.715 & 1.695 & $1.19 \%$ & $7-1 B$ & 1.676 & 1.651 & $1.53 \%$ \\
\hline $3-1 \mathrm{C}$ & 1.699 & 1.697 & $0.14 \%$ & $7-1 \mathrm{C}$ & 1.681 & 1.662 & $1.17 \%$ \\
\hline 3-1D & 1.750 & 1.705 & $2.62 \%$ & $7-1 D$ & 1.706 & 1.674 & $1.88 \%$ \\
\hline $4-1 \mathrm{~A}$ & 1.672 & 1.612 & $3.70 \%$ & 8-1A & 1.637 & 1.595 & $2.64 \%$ \\
\hline $4-1 B$ & 1.683 & 1.633 & $3.06 \%$ & 8-1B & 1.685 & 1.642 & $2.58 \%$ \\
\hline $4-1 \mathrm{C}$ & 1.690 & 1.656 & $2.06 \%$ & $8-1 C$ & 1.700 & 1.643 & $3.50 \%$ \\
\hline 4-1D & 1.710 & 1.677 & $1.92 \%$ & 8-1D & 1.716 & 1.667 & $2.89 \%$ \\
\hline
\end{tabular}

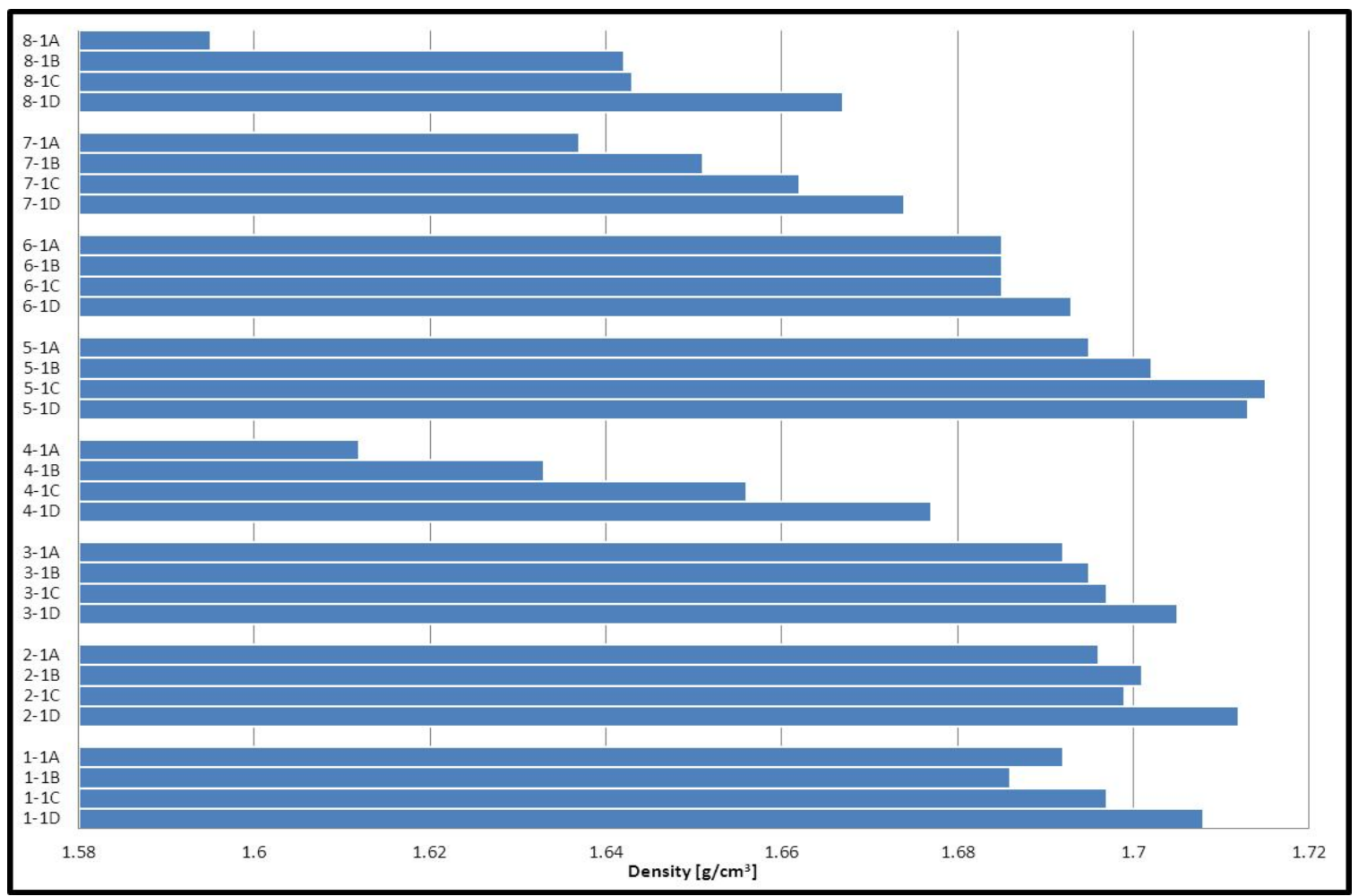

Figure 3-1. Density of Sectioned Monoliths

The reason for measuring the density by two different methods was to verify that the pycnometer is a viable method for measuring the density of saltstone samples. Performing ASTM C642-06 is time consuming compared to using the pycnometer, so pycnometry would be the preferred 
method of density measurement if appropriate. For these thirty-two measurements, the values obtained from the pycnometer were within four percent of those calculated by ASTM C642-06 in all cases. However it is important to note that the samples measured in the pycnometer must be saturated prior to measurement.

Samples 4 and 8 contained $10 \%$ excess salt solution as standing water present prior to casting. Note that for these two samples, there is a $4-5 \%$ increase in density moving from the top to the bottom sections. This is indicative of settling of the saltstone before it is set.

\subsection{Leachability}

The $\mathrm{pH}$ and electrical conductivity of the collected leachate samples were measured as specified in ANS/ANSI 16.1 and are tabulated in Table 3-2 and in Table 3-3, respectively.

Table 3-2. pH of Leachate Samples

\begin{tabular}{|c|c|c|c|c|c|c|c|c||}
\hline $\begin{array}{c}\text { Sample } \\
\text { ID }\end{array}$ & $\mathbf{3 0 s}$ & $\mathbf{2} \mathbf{h r}$ & $\mathbf{7} \mathbf{h r}$ & $\mathbf{2 4} \mathbf{h r}$ & $\mathbf{4 8} \mathbf{h r}$ & $\mathbf{7 2} \mathbf{~ h r}$ & $\mathbf{9 6} \mathbf{~ h r}$ & $\mathbf{1 2 0} \mathbf{~ h r}$ \\
\hline $\mathbf{1 - 2}$ & 6.57 & 10.41 & 10.78 & 11.33 & 11.35 & 11.35 & 11.18 & 11.11 \\
\hline $\mathbf{2 - 2}$ & 6.93 & 10.04 & 10.34 & 11.01 & 10.34 & 9.65 & 10.85 & 10.77 \\
\hline $\mathbf{3 - 2}$ & 6.99 & 10.29 & 10.61 & 9.63 & 11.05 & 10.95 & 10.88 & 10.82 \\
\hline $\mathbf{4 - 2}$ & 9.77 & 7.94 & 10.85 & 11.13 & 10.99 & 9.80 & 10.89 & 10.84 \\
\hline $\mathbf{5 - 2}$ & 7.32 & 10.44 & 10.51 & 11.45 & 11.49 & 11.30 & 11.23 & 11.23 \\
\hline $\mathbf{6 - 2}$ & 9.59 & 10.14 & 10.85 & 10.65 & 11.15 & 10.95 & 10.06 & 10.94 \\
\hline $\mathbf{7 - 2}$ & 8.08 & 10.42 & 10.70 & 11.13 & 11.15 & 10.26 & 10.92 & 10.87 \\
\hline $\mathbf{8 - 2}$ & 9.47 & 10.54 & 11.00 & 11.26 & 11.27 & 11.06 & 11.07 & 10.88 \\
\hline
\end{tabular}

Table 3-3. Conductivity $(\mu S)$ of Leachate Samples

\begin{tabular}{|c|c|c|c|c|c|c|c|c|}
\hline $\begin{array}{c}\text { Sample } \\
\text { ID }\end{array}$ & $\mathbf{3 0 s}$ & $\mathbf{2} \mathbf{h r}$ & $\mathbf{7} \mathbf{h r}$ & $\mathbf{2 4} \mathbf{h r}$ & $\mathbf{4 8} \mathbf{h r}$ & $\mathbf{7 2} \mathbf{~ h r}$ & $\mathbf{9 6} \mathbf{~ h r}$ & $\mathbf{1 2 0} \mathbf{~ h r}$ \\
\hline $\mathbf{1 - 2}$ & 13.7 & 1118.0 & 1073.0 & 2096.0 & 1630.0 & 1279.0 & 940.0 & 763.0 \\
\hline $\mathbf{2 - 2}$ & 68.0 & 137.0 & 139.7 & 430.0 & 285.4 & 198.2 & 284.7 & 245.3 \\
\hline $\mathbf{3 - 2}$ & 49.3 & 192.0 & 188.3 & 322.0 & 477.0 & 314.0 & 298.0 & 250.6 \\
\hline $\mathbf{4 - 2}$ & 116.8 & 97.1 & 245.5 & 453.0 & 427.0 & 232.8 & 311.0 & 281.5 \\
\hline $\mathbf{5 - 2}$ & 14.3 & 1503.0 & 1203.0 & 2130.0 & 1668.0 & 1221.0 & 1014.0 & 854.0 \\
\hline $\mathbf{6 - 2}$ & 85.9 & 150.4 & 248.6 & 365.0 & 432.0 & 337.0 & 298.0 & 256.8 \\
\hline $\mathbf{7 - 2}$ & 81.0 & 296.3 & 208.2 & 533.0 & 456.0 & 260.6 & 314.0 & 288.2 \\
\hline $\mathbf{8 - 2}$ & 97.0 & 320.0 & 375.0 & 744.0 & 676.0 & 479.0 & 424.0 & 355.0 \\
\hline
\end{tabular}

The conductivity of the leachates from samples 1-2 and 5-2 are higher than the rest of the samples at all sampling intervals after the initial 30 second rinse. These are the leachates from the two samples that were cured exposed to the atmosphere.

To calculate the Leachability Index (LI) for each of the constituents of interest, first the effective diffusivity of each of each species at each leaching interval must be calculated. The inputs to this calculation include the ICP-ES and IC data collected for each leachate sample, the physical dimensions of the samples and the initial amounts of each species in the monoliths prior to leaching. The salt solution composition used is in Table 2-1. The premix composition for the species of interest as measured on a sample from the SPF in 2011 is included in Table 3-4. The cylinder dimensions are in Appendix Table A-1. 
SRNL-STI-2012-00546

Revision 0

Table 3-4. Premix Composition

\begin{tabular}{||c|c|}
\hline Oxide & $\begin{array}{c}\text { Mass fraction } \\
\text { (wt \%) }\end{array}$ \\
\hline $\mathrm{Al}_{2} \mathrm{O}_{3}$ & 15.86 \\
\hline $\mathrm{CaO}$ & 22.19 \\
\hline $\mathrm{K}_{2} \mathrm{O}$ & 1.44 \\
\hline $\mathrm{Na}_{2} \mathrm{O}$ & 0.30 \\
\hline
\end{tabular}

After calculating the effective diffusivity for each species at each sampling interval, the Leachability Index can be calculated per ANS/ANSI 16.1. The Leachability Indices for the nine measured species are included in Table 3-5.

Table 3-5. Leachability Indices

\begin{tabular}{|c|c|c|c|c|c|c|c|c|c||}
\hline $\begin{array}{c}\text { Sample } \\
\text { ID }\end{array}$ & $\mathbf{A l}$ & $\mathbf{C a}$ & $\mathbf{C r}$ & $\mathbf{K}$ & $\mathbf{N a}$ & $\mathbf{R e}$ & $\mathbf{N O}_{\mathbf{2}}$ & $\mathbf{N O}_{\mathbf{3}}$ & $\mathbf{C}_{\mathbf{2}} \mathbf{O}_{\mathbf{4}}$ \\
\hline $\mathbf{1 - 2}$ & 12.7 & 11.4 & $>9.6$ & 8.5 & 7.1 & 7.2 & $>7.2$ & 7.7 & $>5.4$ \\
\hline $\mathbf{2 - 2}$ & 12.5 & 11.8 & $>9.6$ & 10.1 & 8.7 & 9.0 & 8.1 & 8.7 & $>5.4$ \\
\hline $\mathbf{3 - 2}$ & 12.7 & 11.4 & $>9.6$ & 10.5 & 8.7 & 9.3 & 8.1 & 8.8 & $>5.5$ \\
\hline $\mathbf{4 - 2}$ & 12.5 & 11.4 & $>9.7$ & 10.0 & 8.6 & 9.0 & 8.2 & 8.7 & $>5.5$ \\
\hline $\mathbf{5 - 2}$ & 12.6 & 11.3 & $>9.6$ & 8.3 & 7.0 & 7.1 & $>6.8$ & 7.6 & $>5.5$ \\
\hline $\mathbf{6 - 2}$ & 12.4 & 11.5 & $>9.6$ & 10.0 & 8.6 & 8.9 & 8.1 & 8.7 & $>5.5$ \\
\hline $\mathbf{7 - 2}$ & 12.5 & 11.8 & $>9.7$ & 9.8 & 8.5 & 8.8 & 8.1 & 8.5 & $>5.5$ \\
\hline $\mathbf{8 - 2}$ & 12.5 & 11.2 & $>9.8$ & 9.6 & 8.3 & 8.6 & 8.2 & 8.5 & $>5.6$ \\
\hline
\end{tabular}

The calculation for Leachability Index involves a logarithm of the inverse of the effective diffusivity, which will be undefined for a species that is not detected in the leachate. In those cases where one, two, or three of the seven samples did not contain a measurable quantity of the species of interest, only the samples which had a measureable quantity were used in the calculation. For example, the calcium Leachability Index for sample 3-2 used only six of the seven effective diffusivity values in the calculation. For a species which is below the detection limit at all sampling intervals, the detection limit itself can be used in the calculation to determine a lower bound for the Leachability Index.

A smaller Leachability Index indicates that a species is more easily removed from the sample. The results show that samples 1-2 and 5-2 have lower Leachability Indices than the remainder of the samples for potassium, sodium, rhenium, nitrate, and nitrite. Again, samples 1-2 and 5-2 are the samples which were cured exposed to the atmosphere. It is hypothesized that the dry conditions allowed for shrinkage cracks to form in the samples which provided additional pathways for release of the soluble components. There is no noticeable effect on leachability by varying water to premix ratio (samples 1-2 through 4-2 versus samples 5-2 through 8-2) or by the inclusion of excess bleed water.

There was no detectable chromium release in any of the eight samples at any of the leaching time intervals. Rhenium leachability tracks with sodium and nitrate which are the two most soluble, mobile, and prevalent species in the salt solution. 


\subsection{Hydraulic Conductivity}

At the time of writing of this report, the hydraulic conductivity measurements were not yet performed by AMEC. These data will be reported separately when available. ${ }^{10}$

\subsection{Conclusions}

A series of Saltstone mixes were prepared, cast into duplicate molds, and cured at ambient temperature to evaluate the impact of standing bleed water on Saltstone placement. The samples were managed to control drying effects on leachability by either exposing or lidding the samples. The water to premix (w/p) ratio was varied to represent the different processing conditions described in the TTR. Samples were analyzed for density, leachability, and hydraulic conductivity (to be reported).

A monolith of each composition was cut into four sections to analyze the homogeneity of the sample with respect to vertical position within the sample. The density of each section was measured by two methods, helium pycnometry and by ASTM 642-06. The results show a trend of increasing density toward the bottom of the samples. This effect is more pronounced with the inclusion of excess bleed water.

A comparison of the data from the two different density methods verified that use of helium pycnometry is an effective technique for measuring the density of Saltstone samples as an alternative to the labor intensive ASTM method, provided that the samples are saturated prior to performing the measurements.

Leachability of the eight different samples was analyzed by ANS/ANSI 16.1. These results indicate that drying of the Saltstone during curing leads to decreased Leachability Indices (increased leaching) for potassium, sodium, rhenium, nitrite, and nitrate. This may be caused by shrinkage cracking in the samples creating additional pathways for contaminant release.

There is no noticeable effect on Saltstone oxidation/leachability by changing the water to premix ratio or by pouring into standing water.

There was no detectable chromium release in any of the samples. Chromium and rhenium were added in equal amounts to determine whether rhenium might be an acceptable surrogate for chromium, a hazardous material. This testing shows no correlation between the behavior of the two elements, as chromium is not released at detectable levels and rhenium is released at a comparable rate to nitrate, the most prevalent and mobile species in Saltstone.

Hydraulic conductivity results are pending and will be analyzed and published separately when available. Any recommendations for future work will be in that report.

The leachability results further demonstrate that drying of saltstone is detrimental to product quality; however the density data show that additional water may exacerbate settling and lead to inhomogeneity. The ability to control the amount of water added in the Saltstone Disposal Facility and retained in the Disposal Units is important to performance of the emplaced saltstone. 


\subsection{References}

${ }^{1}$ Liner, K.R., “Saltstone Vault Sheet Drain Installation (U),” CBU-ENG-2003-00103, (2003).

${ }^{2}$ Riley, P.J., Tihey, J.R., and Sherburne, D.C., "Engineering Path Forward - Vault 4 Drain Water Collection and Return System Restoration and Actions,” SRR-WSE-2010-00036, (2010).

${ }^{3}$ Staub, A.V., "Impact of Standing Bleed Water on Saltstone Placement," HLW-SSF-TTR-2012-0009, (2012).

${ }^{4}$ Cozzi, A.D., "Task Technical and Quality Assurance Plan for Evaluation of the Impact of Standing Bleed Water on Saltstone Placement," SRNL-RP-2012-00029, (2012).

${ }^{5}$ Reigel, M.M., "Results for the First Quarter 2011 Tank 50 WAC Slurry Sample: Chemical and Radionuclide Contaminant Results," SRNL-STI-2011-0030, (2011).

${ }^{6}$ Harbour, J.R., Edwards, T.B., Hansen, E.K., and Williams, V.J., "Variability Study for Saltstone," WSRC-TR-2005-00447, (2005).

7 "Performance Assessment for the Saltstone Disposal Facility at the Savannah River Site," SRR-CWDA2009-00017, Revision 0, (2003).

8 "American National Standard: Measurement of the Leachability of Solidified Low-level Radioactive Wastes by a Short-term Test Procedure," American Nuclear Society, ANSI/ANS-16.1-2003, July 7, 2003.

${ }^{9}$ Flach, G.P., Jordan, J.M., and Whiteside, T., "Numerical Flow and Transport Simulations Supporting the Saltstone Disposal Facility Performance Assessment," SRNL-STI-2009-00115, Revision 0, (2009).

${ }^{10}$ Cozzi, A.D. and Pickenheim, B.R., "Impact of Standing Water on Saltstone Placement II - Hydraulic Conductivity Data,” SRNS-STI-2012-00576, (2012). 
SRNL-STI-2012-00546

Revision 0

Appendix A. Inputs to Leachability Index Calculations 
SRNL-STI-2012-00546

Revision 0

Table A-1. Leaching sample cylinder dimensions

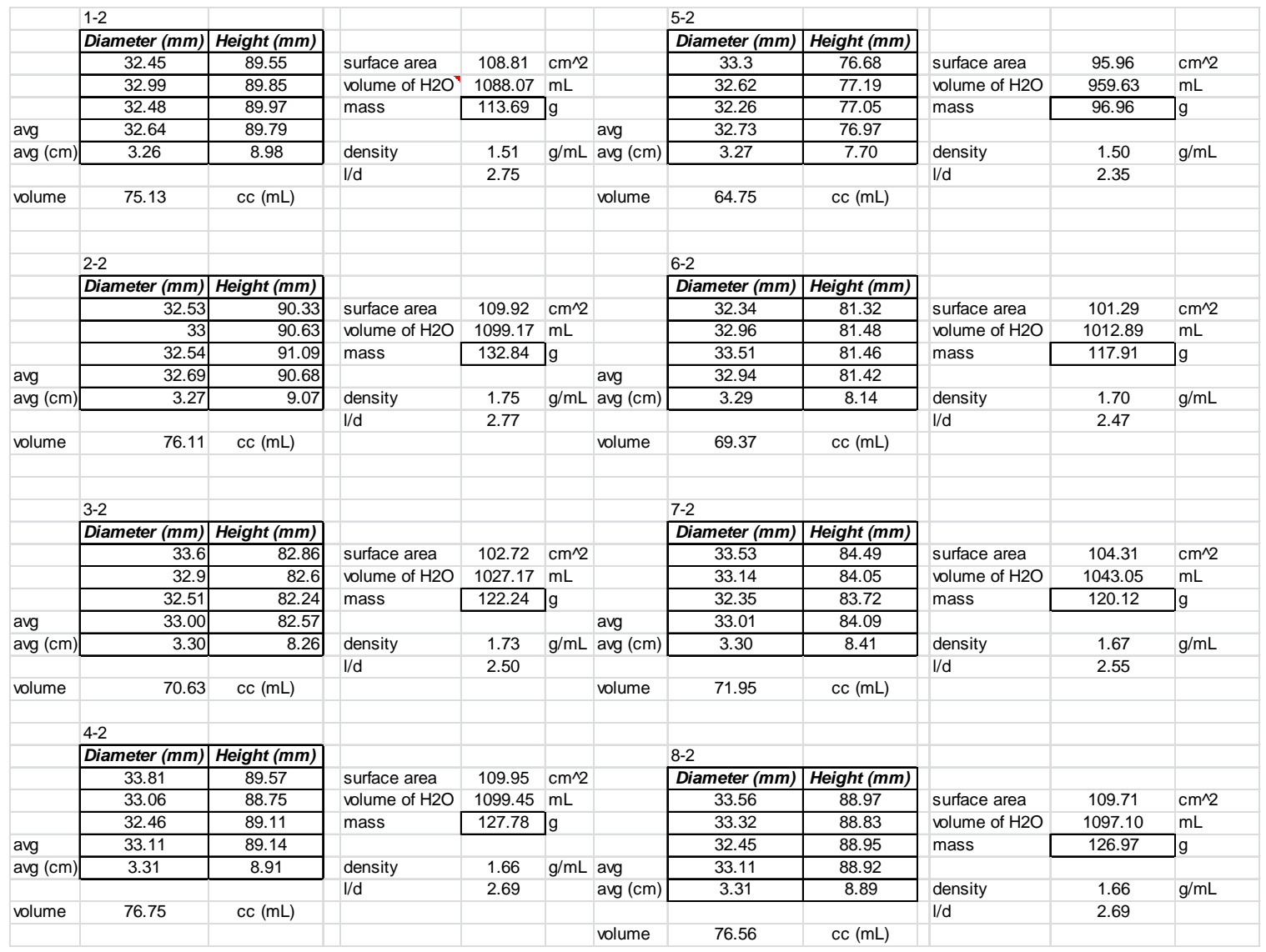




\section{Distribution:}

S. D. Fink, 773-A

K.M. Fox, 999-W

B. J. Giddings, 786-5A

C. C. Herman, 999-W

S. L. Marra, 773-A

F. M. Pennebaker, 773-42A

Records Administration (EDWS)

J. N. Leita, 704-Z

J. R. Tihey, 704-Z

A.V. Staub, 704-27S

J.E. Occhipinti, 704-S

D.C. Sherburne, 704-S

P. R. Jackson, DOE-SR, 703-46A

K. H. Subramanian, 766-H
A.D. Cozzi, 999-W
B.R. Pickenheim, 999-W
M.M. Reigel, 999-W
C.M. Langton, 773-43A
P. M. Almond, 773-43A
E.K. Hansen, 999-W
D.H. Miller, 999-W
R.E. Eibling, 999-W
W.E. Daniel, 999-W 